\title{
Excellence in Cardiovascular Research: The Louis and Artur Lucian Award
}

\author{
Simon Garceau, Alexandre Boutet, Jacques Genest
}

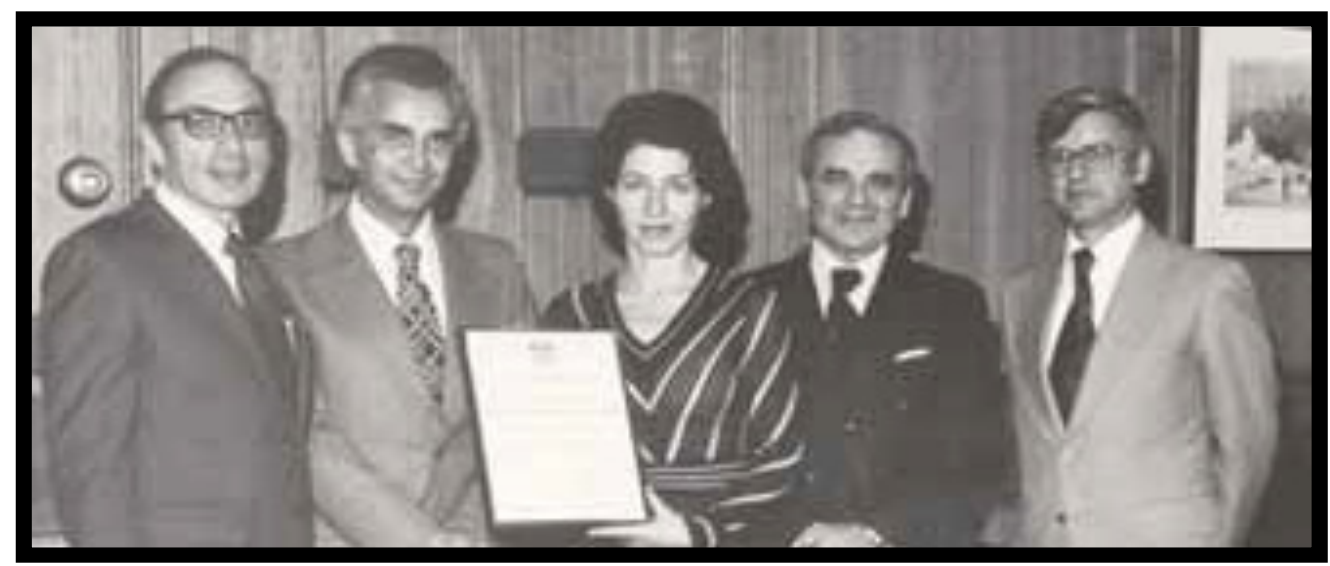

Figure 1. McGill's Louis and Arthur Lucian Award for Research for Circulatory Diseases first presented in October 1978 to Drs Nicolae and Maya Simionescu of Bucharest and Yale Universities for their work in cellular biology and atherosclerotic disease.

From left to right: Alan B. Gold, BA,PhD, chairman of the board of governors of McGill University,Montreal, Quebec, Canada; Dr Nicolae Simionesc; Dr Maya Simionescu; RFP Cronin, MD, a McGill professor in cardiology; Yves Clermont, PhD, chairman of the Department of Anatomy and Histology at McGill University Source: Circulation, Journal of the American Heart Association, 2008.

The Louis and Artur Lucian Award ranks amongst some of the most respected awards presented by an academic institution in the field of cardiovascular disease. Moreover, it represents the largest award bestowed by a Canadian university for research in cardiovascular medicine. Since 1978, the award has honored current work which is deemed to be of outstanding significance in the advancement of the treatment, diagnosis, prevention and understanding of circulatory diseases. Furthermore, the award has a rich history and also aims to promote a partnership between McGill University and Canadian academia with international figures and institutions.

The Lucian award was established in 1965 through a bequest to McGill University by Olga Leibovici, a New-Yorker born in Vaslui, Romania. After meeting with Dr. Ronald V. Christie, at the time dean at the Faculty of Medicine at McGill University,

Frances Handley-Derry

Masters Candidate, Department of Family Medicine McGill University it was decided that a donation of 2 million dollars would be attributed to McGill University for the funding of the Louis and Artur Lucian Award for Research in Circulatory Diseases, named after Mrs. Leibovici's two brothers. A copy of the will from January 21 st, 1965 is provided below.

Since it was first presented to Drs. Nicolae and Maya Simionescu in 1978 for their outstanding work on cellular biology and artherosclerotic disease, the prize has aided numerous globally acclaimed scientists. In fact, a recent recipient, Dr. Robert Lefkowitz, is this year's Nobel laureate in chemistry. His work on G-protein coupled receptors, receptors responsible for sensing and interacting with the body's environment, and the targets of half the medications used today, is unparalleled(1).

Currently, the chair of the Lucian selection committee is Dr. Jacques Genest, a researcher in cardiovascular medicine at McGill University's Royal Victoria Hospital. Each year, a panel composed of previous recipients, McGill graduates 
1) Solxante-dix pour cent $(70 \%)$ de ces revenues ærviront obligatolrement a la creation d'un prix annuel denomme "PRIX DIPL. ING. LOULS LUCIAN ET ARTUR LUCIAN" qu'un jury spectal nomme par la legataire universelle decernera annuellement pour le meilleur ouvrage ou les mellleurs travaux parus dand I'annee dans n'importe quel pays du monde et SE RAPPORTANT AUX MALADIES DES VOIES CIRCULATOIRES. Le beneficiaire du prix sera choisi scrupuleusement a'apres le merite, de quelque pays qu'1l soit et sans distinction de race, religion ou nationalite. Le fury aura le droit de partager ce prix annuel entre deux ou plusieurs.beneficiaires ou bien d'ajourmer pour l'annee suivante ou meme pour deux annees. l'attribution du prix, s'il le jugera a propos.

Figure 2. Excerpt from the Will of the late Olga Leibovici to McGill University for the Creation of the Lucian Award, Courtesy McGill University Faculty of Medicine, Montreal, Quebec, Canada January 21st, 1965 "... Seventy percent of the income fund will obligatorily be used to create an award named "Louis and Artur Lucian (certified Engineers)" awarded annually by a jury nominated by the University for the best work published in the past year anywhere in the world RELATED TO DISEASES OF THE CARDIOVASCULAR SYSTEM. The Awardees will be scrupulously selected, according to merit from any country, without regard to race, religion or nationality. The Jury has the right to share this award between two or more recipients or to defer giving the Award the next year or even two if judged appropriate."

and faculty meet and independently evaluate the 20-30 applicants postulating for any given year. The jury evaluates candidates on present research productivity rather than life-time achievement. "Currently, the award totals $60000 \$$ with hopes to increase this amount to $100000 \$$ over the next five to ten years," says Dr. Genest. Thus, philanthropic donations to McGill University are of great importance in reaching this goal. A key element in raising funds and the university's reputation lies in "building relationships," as pointed out by Marc Weinstein, Vice-principal for development and alumni relations (3). The Lucian award, therefore, wishes to promote international collaborative efforts with McGill University and other Canadian researchers. Each recipient is therefore required to spend a minimum of 1-2 weeks at McGill University to give a formal lecture, interact with the faculty, and possibly undertake collaborative research in the field of circulatory disease with McGill University faculty members.

The current deadline to apply for this year's Lucian Award is March 22nd, 2013. More information on applying for this award can be found at the following website:

http://www.mcgill.ca/lucianaward/ 